\title{
Fermentation, Isolation of Mithramycin from Streptomyces of Playa Region and its Novel Anti- MRSA and Anti-VRE Activity
}

\author{
Sarita V. Bhave, Amarjit V. Sawant, Prashant Shanbhag, Rajashri R. Parab, Prafull V. Ranadive,
} Prabhu Dutt Mishra, Girish B. Mahajan*

Piramal Enterprises Limited, Mumbai, India

Received: July 12, 2015; Accepted: August 20, 2015; Published: September 15, 2015

*Corresponding author: Girish B. Mahajan, Piramal Enterprises Limited, Mumbai, Maharashtra State, India, Pin - 400063, Tel: +91-9821628179; E mail: girishbm2000@gmail.com

\begin{abstract}
A Streptomyces sp. PM1129877 was isolated from the playa region of the state of Rajasthan, India. By bioactivity guided isolation Mithramycin (Plicamycin), a reported antitumor compound was isolated, purified and characterized from the fermented broth of the microbial strain. Antibacterial and Antifungal studies revealed that mithramycin exhibited potent antibacterial properties. It displayed a minimum inhibitory concentration (MIC) range of 0.125-0.25 $\mu \mathrm{g} /$ $\mathrm{ml}$ against methicillin-sensitive Staphylococcus aureus (MSSA) and methicillin-resistant Staphylococcus aureus (MRSA) strains with $\mathrm{MIC}_{90}$ of $0.25 \mu \mathrm{g} / \mathrm{ml}$. Against vancomycin resistant enterococci (VRE) and vancomycin sensitive enterococci (VSE) strains, it displayed an MIC range of $1-16 \mu \mathrm{g} / \mathrm{ml}$ with MIC $_{90}$ of $2.0 \mu \mathrm{g} / \mathrm{ml}$. This is the first report of anti-MRSA and anti-VRE activity by mithramycin. This new use of mithramycin activity can boost the hope for therapeutics against various unmet medical needs associated with these resistant strains.
\end{abstract} VRE

Keywords: Antibacterial; Mithramycin; MRSA, Streptomyces,

\section{Introduction}

Mithramycin (Plicamycin, Mithracin, MIT) is a bright yellow, crystalline solid belonging to a group of aureolic acid type of antibiotics; produced naturally by a variety of Streptomyces sp. especially S. argillaceus, S. plicatus and S. tanashiensis [1-3]. Structurally, it is an aromatic polyketide antibiotic containing aglycon moiety, derived from the series of condensation reactions, catalyzed by a Type II polyketide synthase [4,5]. It is a known antitumor agent and acts on variety of tumor cell lines [68]. Antitumor properties of mithramycin are attributed to its role in inhibition of DNA dependent RNA synthesis. In the presence of $\mathrm{Mg}^{++}$, it cross-links to $\mathrm{G}+\mathrm{C}$ rich regions of DNA, thereby preventing the binding of Sp (specificity proteins) transcription factors, consequently affecting transcription [9-12].

Although majority of work related to mithramycin is concerned with its antitumor properties, it is also known to exhibit activity against Gram positive bacteria $[13,14]$. However, the organisms, Staphylococcus aureus or Bacillus subtilis, have merely been used as a tool in bioassay guided purification of mithramycin [2].

Globally, in last two decades, prevalence of the antibiotic resistance among the MRSA, penicillin-resistant Streptococcus pneumoniae (PRSP) and vancomycin resistant enterococci (VRE) has been observed against variety of antibiotics [15-19]. Moreover, incidences of resistance of Gram positive bacterial infections against the new drugs such as Linezolid and Daptomycin have also been published $[20,21]$. To combat such infections, discovery of novel drugs and/or novel scaffolds is of utmost importance. However new drug discovery is a long term and uncertain process with high expenditure. Another alternative to tackle such problem could be repositioning of the existing bioactive compounds in which known drugs are screened to establish their new bioactivity of desired interest [22]. For example, Rapamycin, a known immunosuppressant drug had been reported to exhibit anticancer activity against primary chronic lymphocytic leukemia cells [23]. Recently new anti-amyloidogenic activity was reported from previously known antibacterial antibiotic tetracycline [24]. Moreover mithramycin as a new candidate for developing new therapeutic drugs for neurodegenerative diseases has also been proposed [25]. Mithramycin has its beneficial effect for not only neurodegenerative diseases, but also a host of others, like cartilage degeneration in osteoarthritis, ER stress mediated apoptosis in hippocampus, erythroid differentiation and fetal haemoglobin production in thalassemia and sickle cell anaemia [26-28]

In the current study, we had isolated, purified and characterized mithramycin from a Streptomyces sp. PM1129877 isolated from a playa region of Thar Desert in Rajasthan, India. This playa region was hardly explored for isolation of actinomycetes producing bioactive compounds. During screening, we observed that mithramycin exhibited potent in-vitro antibacterial activity against variety of Gram positive pathogenic strains of MRSA and VRE. We confirmed these observations by In vitro testing of the compound against variety of Gram positive and Gram negative 
bacteria including resistant strains obtained from clinics and hospitals. This is the first report on the novel activity of mithramycin against the MRSA and VRE strains.

\section{Materials and Methods}

The media ingredients such as Beef extract, Malt extract, Peptone, Yeast extract, Corn steep liquor etc. used for cultivation and fermentation of microbes were obtained from Hi Media Laboratories Pvt. Ltd, India. Salts such as $\mathrm{NaCl}, \mathrm{CaCO}_{3} \mathrm{NaNO}_{3}$ etc were procured from Merck Specialties Pvt. Ltd, India.

The normal phase flash chromatography was performed on CombiFlash $\mathrm{R}_{\mathrm{f}}$ (Teledyne isco) using Redicep $\mathrm{R}_{\mathrm{f}} 20 \mathrm{~g}$ silica column. HPLC analysis and UV spectra were monitored on Shimadzu LC-2010- PDA instrument (Shimadzu, Kyoto, Japan). The data were processed with LC-solution software (Shimadzu, Kyoto, Japan). Distilled LR grade solvents were used for column chromatography and TLC, HPLC grade solvents from Merck were used for preparative and analytical HPLC. TLC Silica gel $60 \mathrm{~F}_{25}$ plates were from Merck Specialties Pvt. Ltd, India. The NMR spectra were recorded on Bruker Avance at $500 \mathrm{MHz}$.

\section{Sample collection, isolation and fermentation of the organism}

Soil samples were collected from playa region of Pokhran $\left(26.92^{\circ} \mathrm{N} 71.92^{\circ} \mathrm{E}\right)$, a remote region surrounded by rocky, sandy hills and salt lakes, located in Jaisalmer district in Thar Desert of Rajasthan state in India. The playa is a flat barren land in desert like areas with few shrubs and salt depositions seen intermittently. Pokhran playa is approximately $12 \mathrm{sq} \mathrm{Km}$ area of semi-arid loose sandy soil characterized with high concentrations of halite and traces of calcite, gypsum, proto-dolomite and anhydrite as a result of low rainfall and high evaporation to precipitation rate. The genetic identity and novelty of microbial extremophiles (i.e., bacteria, archaea, and protists) of this area remains largely unexplored [29]. The surface soil samples were collected with a sterile spatula and stored in sterile polythene containers. These samples were stored at ambient temperature and processed for microbial isolation at research centre of Piramal Enterprises Ltd., Mumbai, India.

Approximately $0.5 \mathrm{~g}$ of the collected sandy soil was suspended in $5 \mathrm{ml}$ sterile saline $(8.5 \mathrm{~g} / \mathrm{l} \mathrm{NaCl}$ in demineralised water) and vortexed for $1 \mathrm{~min}$. This was diluted serially $1: 10$ up to $10^{-3} .200$ $\mu \mathrm{l}$ of $10^{-3}$ dilution of the soil suspension was surface spread on modified Bennet's agar medium containing (g/l), Glucose 10, Casamino acids 2, Yeast Extract 2, Beef Extract 2, Agar powder 15, final pH 7.2-7.5, supplemented with $50 \mathrm{~g} / \mathrm{l} \mathrm{NaCl}$. The plates were incubated at $25 \pm 1^{\circ} \mathrm{C}$ for $2-3$ weeks and observed regularly for appearance of actinomycetes colonies. The producer strain of the mithramycin was one such isolate. The isolate was picked up, purified and maintained on modified ISP2 medium slants containing (g/l), Glucose 40, Yeast extract 40, Malt extract 100, Agar powder 15, final pH 7.5, supplemented with $50 \mathrm{~g} / \mathrm{l} \mathrm{NaCl}$. The isolate was designated with code PM1129877.

A loopful of growth from 15 days old slant of this strain PM1129877 was inoculated in 274 (1) seed medium containing (g/l), Glucose 15, Peptone 7.5, Yeast extract 7.5, Corn steep liquor $5, \mathrm{NaCl} 5, \mathrm{CaCO}_{3} 2, \mathrm{pH}$ was adjusted to 7.5 . The culture was incubated on shaker at $200 \mathrm{rpm}$ for $72 \mathrm{~h}$ at $30^{\circ} \mathrm{C} .4 \%(\mathrm{v} / \mathrm{v})$ of seed inoculum was added in $20 \mathrm{~L}$ production medium $1 \mathrm{M}$ containing (g/l), Glycerol 30, Glucose 3, Peptone 3, Yeast extract 2, $\mathrm{CaCO}_{3} 3$, $\mathrm{NaNO}_{3} 1, \mathrm{NaCl} 30$, final $\mathrm{pH}$ 7.5. The medium was supplemented with $15 \mathrm{~g} / \mathrm{l}$ additional $\mathrm{NaCl}$. The 200 production medium flasks (each containing $100 \mathrm{ml}$ medium in $1 \mathrm{~L}$ capacity flasks) were incubated on shaker at $200 \mathrm{rpm}$ for $96 \mathrm{~h}$ at $30^{\circ} \mathrm{C}$. After incubation, contents of the flasks were pooled together and representative sample $(100 \mathrm{ml})$ of this whole broth was extracted with equal volume of methanol under shaking condition for $1.5 \mathrm{~h}$ at $30^{\circ} \mathrm{C}$. The contents were centrifuged and supernatant (Methanolic extract of whole broth, as mentioned in Table 1) was screened against Gram positive and Gram negative bacterial test cultures and yeasts and fungal test cultures. Antimicrobial activity was determined by whole cell agar well diffusion bioassay by boring 6 $\mathrm{mm}$ diameter wells in agarified medium and adding $50 \mu \mathrm{l}$ samples to be tested in it [30]. Vancomycin $(20 \mu \mathrm{g} / \mathrm{ml})$, Gentamicin (50 $\mu \mathrm{g} / \mathrm{ml})$ and Amphotericin B $(20 \mu \mathrm{g} / \mathrm{ml})$ were used as standard antibiotics for Gram positive bacteria, Gram negative bacteria and fungi respectively. Absolute methanol was used as solvent control.

\section{Isolation, purification and characterization of the active compound}

$20 \mathrm{~L}$ of whole fermented broth was stirred with equal volume of absolute methanol for $1.5 \mathrm{~h}$ and the filtrate was concentrated to its half the volume under reduced pressure at $45^{\circ} \mathrm{C}$. The concentrate was subjected to HP-20 resin adsorption chromatography and stirred for $1.5 \mathrm{~h}$. Then HP-20 resin was washed with de-mineralised (DM) water and eluted with $80 \%$ aqueous methanol followed by absolute methanol. Both methanolic eluates were pooled and concentrated under reduced pressure at $40^{\circ} \mathrm{C}$ to obtain crude extract. The extract was subjected to normal phase (Silica gel, 100-200 mesh) flash column chromatography and the compounds were eluted by increasing proportion of ethyl acetate in petroleum ether. The fractions were pooled based on the similar silica TLC pattern (Mobile phase; Methanol: $\mathrm{CHCI}_{3}=1: 9$ ) observed at UV $254 \mathrm{~nm}$. The bioactivity data indicated that active components were eluted by $20 \%$ ethyl acetate in petroleum ether. The final purification up to $99.5 \%$ was achieved by preparative HPLC. The pure compound was analyzed by analytical HPLC \{(Column: LiChrospher, RP-

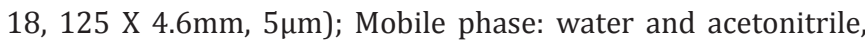
$98 / 0,0 / 15,0 / 20,98 / 21,98 / 25$ (\% water/time in min)\}. The compound was analyzed by LC-ESI MS on Micro QTOF of Bruker Daltonics. DMDO-d6 was used as solvent for these experiments and chemical shifts were referenced to the solvent peak at 2.50 ppm. The UV spectrum was obtained from a HPLC-photodiode array analysis of the compound using 15\% acetonitrile/water [31].

\section{Determination of minimum inhibitory concentration (MIC) values}

The potency of purified mithramycin was determined by generating MIC values by the NCCLS (CLSI) macro-broth dilution 


\begin{tabular}{|c|c|c|c|c|c|c|c|c|c|}
\hline \multicolumn{10}{|c|}{ (zone of inhibition around the well in $\mathrm{mm}$, well diameter $6 \mathrm{~mm}$ ) } \\
\hline $\begin{array}{l}\text { Details of samples used } \\
\text { in whole cell agar well } \\
\text { diffusion assay }\end{array}$ & $\begin{array}{l}\text { S. aureus } \\
\text { 209P, } \\
\text { MSSA }\end{array}$ & $\begin{array}{l}\text { S. aureus } \\
\text { ATCC } \\
\text { 33591, } \\
\text { MRSA }\end{array}$ & $\begin{array}{l}\text { E. faecium } \\
\text { R-2-323, } \\
\text { VRE }\end{array}$ & $\begin{array}{l}\text { E. faecalis } \\
\text { ATCC } \\
\text { 51575, } \\
\text { VRE }\end{array}$ & $\begin{array}{c}\text { E. coli } \\
\text { ATCC20732 }\end{array}$ & $\begin{array}{l}\text { C. albicas } \\
\text { HMR }\end{array}$ & $\begin{array}{l}\text { C. krusei } \\
\text { G03, } \\
\text { Fluc }^{\mathrm{R}}\end{array}$ & $\begin{array}{l}\text { C. glabrata } \\
\text { H05, Fluc }^{\mathrm{R}}\end{array}$ & $\begin{array}{c}\text { A. fumigatus, } \\
\text { HMR }\end{array}$ \\
\hline $\begin{array}{l}\text { Methanolic whole broth of } \\
\text { the organism }\end{array}$ & 29 & 28 & 25 & 22 & - & $9 \mathrm{vh}$ & $9 \mathrm{~h}$ & - & $12 \mathrm{~h}$ \\
\hline Vancomycin $(20 \mu \mathrm{g} / \mathrm{ml})$ & 15 & 14 & 14 & $9 \mathrm{~h}$ & NT & NT & NT & NT & NT \\
\hline Gentamicin $(50 \mu \mathrm{g} / \mathrm{ml})$ & NT & NT & NT & NT & 15 & NT & NT & NT & NT \\
\hline Amphotericin B $(20 \mu \mathrm{g} / \mathrm{ml})$ & NT & NT & NT & NT & NT & 18 & 16 & 17 & 19 \\
\hline Methanol & - & - & - & - & - & - & - & - & - \\
\hline \multicolumn{10}{|c|}{$\begin{array}{l}\text { NT: Not tested } \\
\text { Fluc: Fluconazole resistant } \\
\text { vh: very hazy zone of inhibition } \\
\text { h: hazy zone of inhibition } \\
-: \text { No zone of inhibition }\end{array}$} \\
\hline
\end{tabular}

method for aerobic bacteria M7-A5 [32]. Linezolid was used as a standard compound as it is currently used in clinic as therapeutic agent for MRSA infections. Mithramycin was suitably diluted in the concentration range of $0.0078-16 \mu \mathrm{g} / \mathrm{ml}$. The concentration range for Linezolid used was $0.019-16 \mu \mathrm{g} / \mathrm{ml}$. Absolute methanol was used as a solvent for making stock solutions of test compounds. Muller Hinton broth with two fold serial dilution of the compound was inoculated with $10^{5}$ colony forming units $/ \mathrm{ml}$ of test culture and incubated at $37^{\circ} \mathrm{C}$ for $24 \mathrm{hr}$. The visible growth (turbidity visible to naked eyes) was noted from each tube and the MIC values were recorded. The MIC of mithramycin was determined against 45 test organisms which included 37 Gram positive and 8 Gram negative clinical, in house and standard American Type Culture Collection (ATCC) strains.

\section{Test organisms for bioactivity estimation}

The bacterial test strains included Gram positive strains (total 37) obtained from in house strain bank of Hoechst Marion Roussel Ltd, India viz. S. aureus 209P MSSA, S.aureus E710 MRSA, Enterococcus faecium R-2-323 VRE (VanA), E. faecium R-2-322 VSE, E. faecalis-321 VSE, Bacillus subtilis-122, B. megaterium FH 1127, B. licheniformis ATCC 21552; standard strains procured from the American Type Culture Collection (ATCC), Manassas, USA included, S. aureus ATCC 33591 MRSA, E. faecium ATCC 51559 [Multidrug-resistant (ampicillin, ciprofloxacin, gentamicin, rifampin, teicoplanin, and vancomycin; $\operatorname{van}^{+}$)], E. faecalis ATCC 51575 VRE, E. faecalis ATCC BAA 472 VRE, E. faecalis ATCC 51299 VRE (VanB) and B. subtilis ATCC 6633. 13 MRSA and 10 VRE strains were procured from private and government clinics/ hospitals in Mumbai-India.

Gram negative strains (total 8) obtained from in house strain bank of Hoechst Marion Roussel Ltd. India, included Escherichia coli ATCC 20732, E. coli ATCC 25922, E. coli ATCC 35218, Pseudomonas aeruginosa M-35; standard strains procured from the American Type Culture Collection (ATCC), Manassas, USA included, $P$. aeruginosa ATCC 27853, P. aeruginosa ATCC BAA

\section{7, Acinetobacter baumannii ATCC 19606 and A.baumannii ATCC} BAA 747.

The fungal test strains used in agar well diffusion assay of fermented broth included Candida albicans HMR, Candida krusei G03 Fluc ${ }^{\mathrm{R}}$, Candida glabrata $\mathrm{HO} 5$ Fluc $^{\mathrm{R}}$ and Aspergillus fumigatus HMR. These test strains were obtained from in house strain bank of Hoechst Marion Roussel Ltd, India.

\section{Results and Discussion}

\section{The organism and its bioactivity}

The colony of the producer strain PM1129877; which was picked after 2-3 weeks of incubation was leathery and surrounded by halo of translucent mycelia. It was circular to ovoid, 3-5 mm in diameter, with shining rough surface, convex with pointed tip, having yellow ochre substrate mycelia but devoid of aerial mycelia, sporulation and diffused pigments. On the basis of its morphological features, the organism was identified to be belonging to the genus Streptomyces. The culture (PM1129877) was deposited in Microbial Culture Collection [International Depositary Authority (IDA) at National Centre for Cell Science], Department of Biotechnology, Government of India] Pune, Maharashtra 411021- India.

The sample generated from methanolic whole broth extraction of PM1129877, had yellow color and exhibited exclusive and potent activity against Gram positive test cultures with very slight or no activity against yeasts/fungal and Gram negative test cultures (Table 1). For bioassay guided isolation of the compound, only Gram positive bacterial test cultures were selected.

\section{Structural determination}

The molecular weight of the compound $\mathrm{m} / \mathrm{z} \quad 1084.5$ corresponded to the molecular formula $\mathrm{C}_{52} \mathrm{H}_{76} \mathrm{O}_{24}$ of mithramycin (Table 2). The isolated compound (Figure 1 to Figure 4) was confirmed as mithramycin by different spectroscopic analysis 


\begin{tabular}{|l|l|}
\hline \multicolumn{2}{|l|}{ Table 2: Physical and Chemical Properties of Mithramycin. } \\
\hline Appearance & Yellow solid \\
\hline Molecular formula & $\mathrm{C}_{52} \mathrm{H}_{76} \mathrm{O}_{24}$ \\
\hline Molecular weight & 1084.5 \\
\hline LC-MS $(\mathrm{m} / \mathrm{z})$ & $1083.5[\mathrm{M}+\mathrm{H}]$ \\
\hline UV $\lambda_{\max }$ Neutral nm & $229,272,317$ and 412 \\
\hline Solubility & Methanol, DMSO \\
\hline Melting point & $180-184^{\circ} \mathrm{C}$ \\
\hline
\end{tabular}

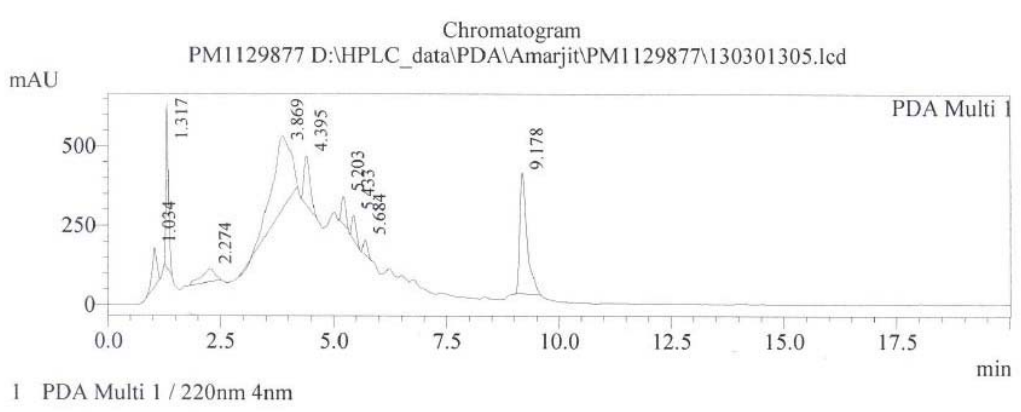

Figure 1: HPLC analysis of concentrate of methanolic eluate of HP20 resin (Arrow indicates Mithramycin peak).

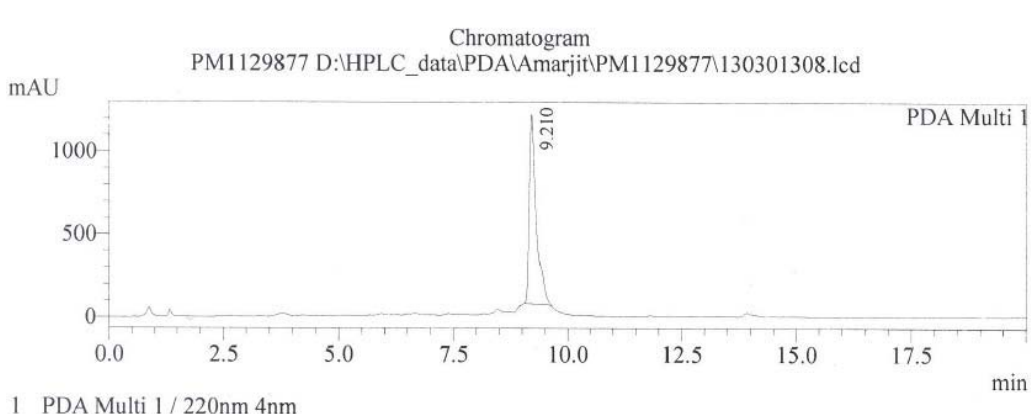

Figure 2: HPLC analysis of pure Mithramycin.

(Table 3 and Figure 3 ) such as LC-MS and ${ }^{1}$ H NMR data [31,33,34].

\section{Determination of potency of mithramycin by MIC estimation}

Mithramycin exhibited potent growth inhibitory activity against Gram positive bacterial strains (Table 4), especially against clinical, resistant strains of MRSA and VRE. It inhibited the growth of MSSA and MRSA strains of $S$. aureus in the MIC range of $0.125-0.25 \mu \mathrm{g} / \mathrm{ml}$ with $\mathrm{MIC}_{90}$ value of $0.25 \mu \mathrm{g} / \mathrm{ml}$. It also displayed activity against vancomycin resistant and vancomycin sensitive strains of Enterococci exhibiting MIC range of1-16 $\mu \mathrm{g} /$ ml with $\mathrm{MIC}_{90}$ value of $2 \mu \mathrm{g} / \mathrm{ml}$. Clinical strains of Enterococci were inhibited in the MIC range of $1-2 \mu \mathrm{g} / \mathrm{ml}$ with MIC $_{90}$ value of $2 \mu \mathrm{g} / \mathrm{ml}$. Bacillus spp. were also strongly inhibited with MIC range of $0.031-1 \mu \mathrm{g} / \mathrm{ml}$.

Apart from MIC estimation, mithramycin was also subjected to agar well diffusion assay against 8 Gram negative strains
(Table 4) up to $256 \mu \mathrm{g} / \mathrm{ml}$ concentration. There was no zone of inhibition around any agar well for any of these test cultures, indicating mithramycin was ineffective against Gram negative test organisms. These results indicated that perhaps mithramycin was unable to penetrate the outer cell membrane barrier of the Gram negative test organisms and hence exhibited specific in vitro activity against different Gram positive test organisms only.

We started the present study with a hope to find a new antimicrobial compound, from microorganism, isolated from soil collected from untapped natural habitat, such as from playa region. In this journey, although we discovered a known molecule, mithramycin, it exhibited novel bioactivity against MRSA and VRE strains. Mithramycin with brand name Mithracin ${ }^{\circledR}$ was available in the market and was also FDA approved for the treatment of testicular cancer and for the treatment of hypercalcemia [35]. Despite hepatotoxicity and nephrotoxicity problems and other side effects, recently there 


\begin{tabular}{|c|c|c|}
\hline $\mathbb{V} / g_{\text {Piramal }}$ & $\begin{array}{c}\text { Piramal Enterprises Limited } \\
\text { Piramal Life Sciences }\end{array}$ & $\begin{array}{l}\text { Sample ID: } 5125-24-3 \mathrm{~B} \\
\text { Solvent: DMSO-d6 } \\
\text { Method: 1H Spectrum } \\
\text { Instrument No: AS-I-09 } \\
\text { Analyst: Rajendra } \\
\text { Date : } 29.08 .2013\end{array}$ \\
\hline
\end{tabular}

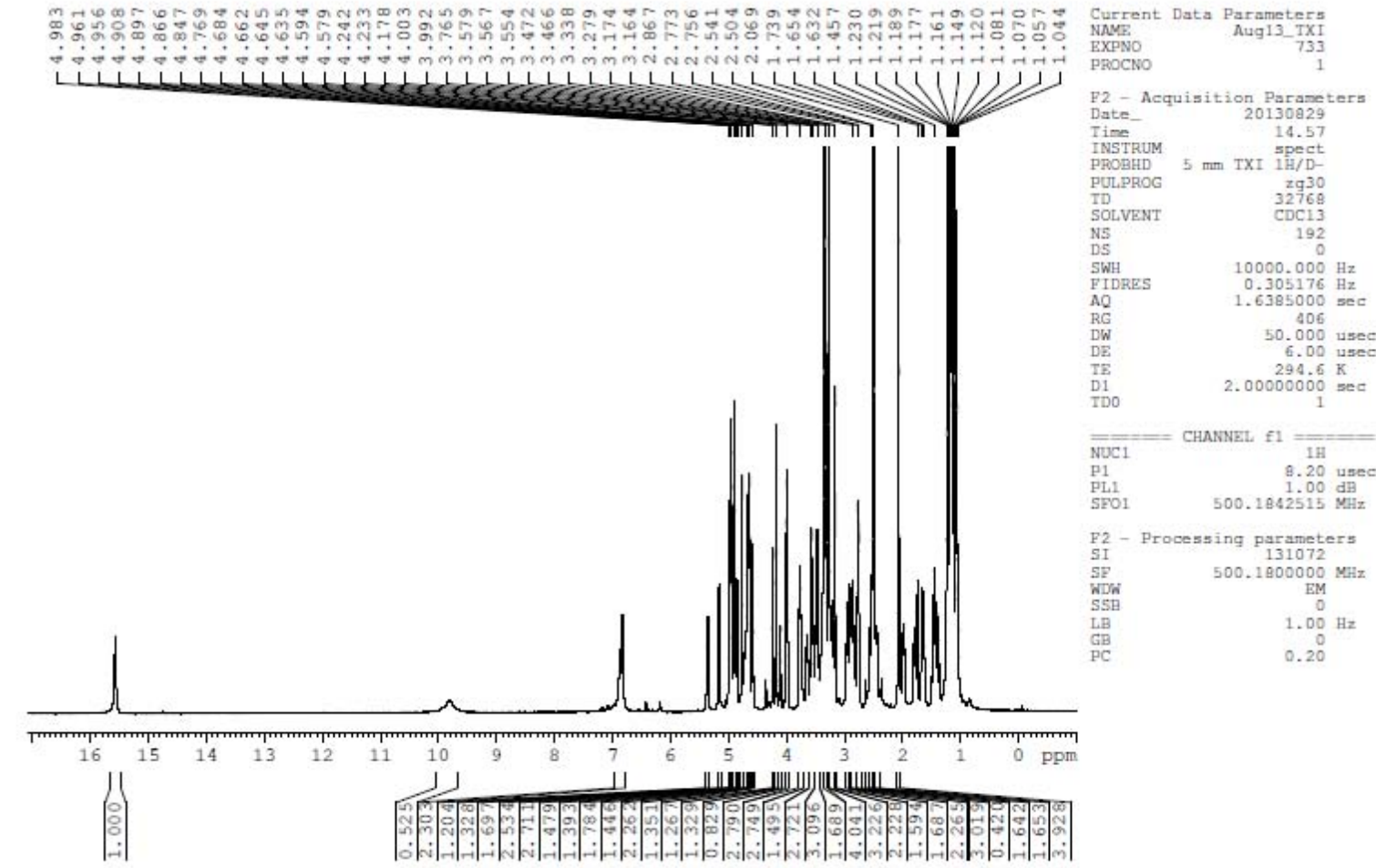

Figure 3: $\mathrm{H}^{+} \mathrm{NMR}$ of Mithramycin

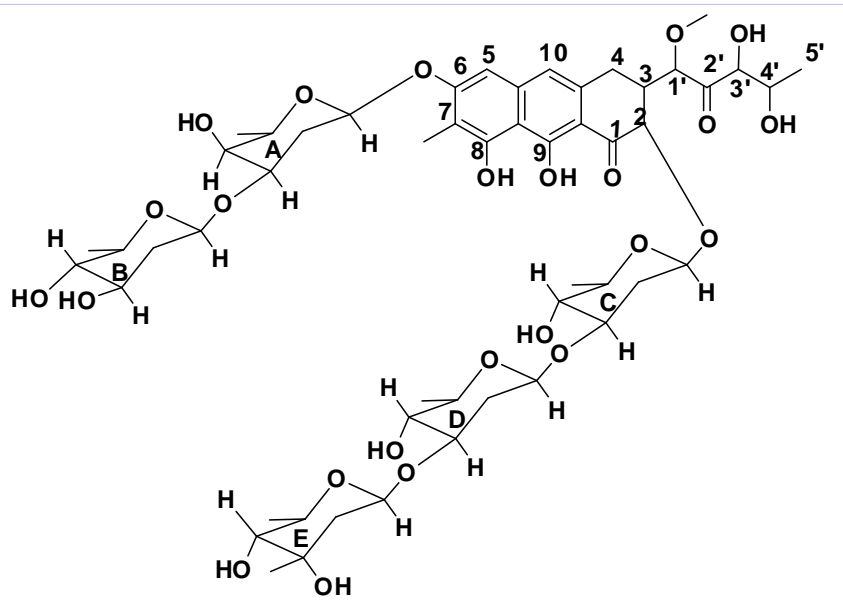

Figure 4: Chemical structure of Mithramycin.

has been renewed interest in aureolic acid class of compounds especially mithramycin, pertaining to new uses and activities such as inhibition of apoptosis and antiangiogenic activity [36]. Moreover clinical trials for mithramycin especially in cancer have also been started recently in USA with sponsorship of NCI $[37,38]$ . This indicates that pharmaceutical researchers still have not lost hope for mithramycin, to be used as a drug candidate in future.
Although from the beginning mithramycin had always been presented as an antitumor drug candidate, as described in Introduction section, recently it has also been proposed as a potential candidate for developing new therapeutic drugs for various other disorders. Similarly, we endeavored to exploit mithramycin for anti-MRSA and anti-VRE activity. Extensive STN (Scientific and Technical Information Network) and other 
Table 3: ${ }^{1} \mathrm{H}$ NMR Data of Mithramycin.

\begin{tabular}{l|l}
${ }^{1} \mathrm{H}$ Data of mithramycin & ${ }^{1} \mathrm{H}$ Data of mithramycin
\end{tabular} (DMSO - $\mathrm{d}_{6}, 500 \mathrm{MHz}$ )

(DMSO - $\mathrm{d}_{6}, 500 \mathrm{MHz}$ )

\begin{tabular}{|c|c|c|c|c|c|}
\hline Position & $\boldsymbol{\delta} \mathbf{H}$ & $\begin{array}{c}\text { Multiplic- } \\
\text { ity }\end{array}$ & Position & $\boldsymbol{\delta} \mathbf{H}$ & $\begin{array}{c}\text { Multiplic- } \\
\text { ity }\end{array}$ \\
\hline 1 & - & - & $1 \mathrm{~B}$ & 4.63 & $\mathrm{dd}$ \\
\hline 2 & 4.64 & $\mathrm{~d}$ & $2 \mathrm{Ba}$ & 1.65 & $\mathrm{ddd}$ \\
\hline 3 & 2.75 & dddd & $2 \mathrm{Be}$ & 2.46 & $\mathrm{ddd}$ \\
\hline 4 & 3.1 & $\mathrm{dddd}$ & $3 \mathrm{~B}$ & 4.9 & $\mathrm{ddd}$ \\
\hline 4 & 2.97 & $\mathrm{dddd}$ & $4 \mathrm{~B}$ & 4.71 & $\mathrm{dd}$ \\
\hline $4 \mathrm{a}$ & - & - & $5 \mathrm{~B}$ & 3.46 & $\mathrm{dq}$ \\
\hline 5 & 6.87 & $\mathrm{~s}$ & $6 \mathrm{~B}$ & 1.21 & $\mathrm{~d}$ \\
\hline 6 & - & - & $1 \mathrm{C}$ & 4.99 & $\mathrm{dd}$ \\
\hline 7 & - & - & $2 \mathrm{Ca}$ & 1.73 & $\mathrm{ddd}$ \\
\hline $\mathrm{CH}_{3}-7$ & 2.06 & $\mathrm{~S}$ & $2 \mathrm{Ce}$ & 2.63 & $\mathrm{ddd}$ \\
\hline 8 & - & - & $3 \mathrm{C}$ & 4.09 & $\mathrm{ddd}$ \\
\hline $8-\mathrm{OH}$ & 9.81 & $\mathrm{~s}$ & $4 \mathrm{C}$ & 4.64 & $\mathrm{dd}$ \\
\hline 9 & - & - & $5 \mathrm{C}$ & 3.46 & $\mathrm{dq}$ \\
\hline
\end{tabular}

\begin{tabular}{|c|c|c|c|c|c|}
\hline $9-\mathrm{OH}$ & 15.57 & $\mathrm{~s}$ & $6 \mathrm{C}$ & 1.21 & $\mathrm{~d}$ \\
\hline 10 & 6.82 & $\mathrm{~s}$ & $1 \mathrm{D}$ & 4.57 & $\mathrm{dd}$ \\
\hline $10 \mathrm{a}$ & - & - & $2 \mathrm{Da}$ & 1.73 & $\mathrm{ddd}$ \\
\hline $1^{\prime}$ & 4.59 & $\mathrm{~d}$ & $2 \mathrm{De}$ & 1.97 & $\mathrm{ddd}$ \\
\hline $\mathrm{OCH}_{3}-1^{\prime}$ & Overlapped with solvent & $3 \mathrm{D}$ & 4 & $\mathrm{dt}$ \\
\hline $2^{\prime}$ & - & - & $4 \mathrm{D}$ & 4.99 & $\mathrm{dd}$ \\
\hline $3^{\prime}$ & 5.17 & $\mathrm{~d}$ & $5 \mathrm{D}$ & 3.56 & $\mathrm{dq}$ \\
\hline $4^{\prime}$ & 5.3 & $\mathrm{~d}$ & $6 \mathrm{D}$ & 1.16 & $\mathrm{~d}$ \\
\hline $5{ }^{\prime}$ & 1.36 & $\mathrm{~d}$ & $1 \mathrm{E}$ & 4.89 & $\mathrm{dd}$ \\
\hline $1 \mathrm{~A}$ & 4.96 & $\mathrm{dd}$ & $2 \mathrm{Ea}$ & 1.5 & $\mathrm{dd}$ \\
\hline $2 \mathrm{Aa}$ & 1.97 & $\mathrm{ddd}$ & $2 \mathrm{Ee}$ & 1.99 & $\mathrm{dd}$ \\
\hline $2 \mathrm{Ae}$ & 2.46 & $\mathrm{ddd}$ & $3 \mathrm{E}$ & - & - \\
\hline $3 \mathrm{~A}$ & 4 & $\mathrm{ddd}$ & $3 \mathrm{E}-\mathrm{CH}_{3}$ & 1.12 & $\mathrm{~s}$ \\
\hline $4 \mathrm{~A}$ & 4.71 & $\mathrm{dd}$ & $4 \mathrm{E}$ & 4.57 & $\mathrm{~d}$ \\
\hline $5 \mathrm{~A}$ & 3.63 & $\mathrm{dq}$ & $5 \mathrm{E}$ & 3.78 & $\mathrm{dq}$ \\
\hline $6 \mathrm{~A}$ & 1.18 & $\mathrm{~d}$ & $6 \mathrm{E}$ & 1 & $\mathrm{D}$ \\
\hline
\end{tabular}

Table 4: In vitro Antibacterial Activity of Mithramycin (MIC Expressed in $\mu \mathrm{g} / \mathrm{ml}$ ).

\begin{tabular}{|c|c|c|c|c|c|c|}
\hline \multirow[t]{2}{*}{ Test culture (n) } & \multicolumn{3}{|c|}{ Mithramycin } & \multicolumn{3}{|c|}{ Linezolid } \\
\hline & MIC range & $\mathrm{MIC}_{50}$ & $\mathrm{MIC}_{90}$ & MIC range & $\mathrm{MIC}_{50}$ & $\mathrm{MIC}_{90}$ \\
\hline S. aureus MRSA* (15) & $0.125-0.250$ & 0.125 & 0.25 & $2.00-8.00$ & 4.00 & 4.00 \\
\hline S. aureus 209P MSSA (1) & 0.125 & - & - & 4.00 & - & - \\
\hline E.faecalis VRE (3) & 2.00 & - & - & 4.00 & - & - \\
\hline E.faecalis VSE (1) & 2.00 & - & - & 4.00 & - & - \\
\hline E.faecium VRE (2) & $1.00-16$ & - & - & $2.00-4.00$ & - & - \\
\hline E.faecium VSE (1) & 4.00 & - & - & 2.00 & - & - \\
\hline Clinical Enterococci spp.VRE (10) & $1.00-2.00$ & 1.00 & 2.00 & $2.00-4.00$ & 2.00 & 4.00 \\
\hline Bacillus spp. (4) & $0.031-1.00$ & - & - & $1.00-2.00$ & - & - \\
\hline $\begin{array}{l}\text { Gram Negatives [E.coli strains (3), Acinetobacter } \\
\text { baumannii strains (2), Pseudomonas spp.(3)] (8) }\end{array}$ & $>16$ & - & - & NT & NT & NT \\
\hline \multicolumn{7}{|c|}{$\begin{array}{l}\text { MRSA: methicillin-resistant Staphylococcus aureus } \\
\text { MSSA: methicillin-sensitive Staphylococcus aureus } \\
\text { VRE: vancomycin-resistant enterococci } \\
\text { VSE: vancomycin susceptible enterococcus } \\
\text { n: number of test strains } \\
\text { *: including } 13 \text { clinical strains and two standard ATCC strains } \\
\text { NT: Not tested }\end{array}$} \\
\hline
\end{tabular}

literature searches carried out by us, showed that mithramycin has not been reported for activity against MRSA and VRE strains, making the present report as the first established report of mithramycin, exhibiting potent antibacterial activity against MRSA and VRE strains.

Development of a drug as an antibiotic needs mode of action studies along with in vivo susceptibility data. At present outcome of such studies for mithramycin cannot be predicted. However, considering the ever increasing cost of new drug discovery program all over the world, reports of challenges faced by Linezolid [20] and Daptomycin [21] and over all the grave problem of resistance of staphylococci and enterococci to these established drugs [16], this study can make scientists revisit the use of mithramycin scaffold, despite its toxicity and side effects.

As confirmed by In vitro studies, mithramycin has potent antibacterial activity. This may be one of the important multiple factors, facilitating dose reduction, required for treating infected animals as compared to high dose regimen of the compound required for the treatment of cancer. Moreover, cancer treatment being a long term process, frequency of occurrence of unpleasant 
side effects of mithramycin is much more. In contrast, treatment for infectious diseases can be completed in limited period of time and toxic side effects of mithramycin can be minimized considerably.

Recently Nunez et al. [39] reported novel mithramycin analogue (demycarosyl-3D- $\beta$-d-digitoxosylmithramycin SK) with high antitumor activity and less toxicity. So alternatively, mithramycin can be used as a 'much needed potential scaffold' for synthesis of less toxic analogs which can also act as antiMRSA drugs. As mithramycin is a known compound, the time and money required for new drug development in infectious disease area can be reduced substantially and in future mithramycin and its analogs would be new leads for the treatment of variety of Gram positive infectious diseases, associated with resistant strains of MRSA and VRE.

In conclusion, mithramycin obtained from Streptomyces sp. PM1129877, isolated from playa region of Thar Desert in Rajasthan, India, was purified and identified using spectroscopic methods. MIC estimations revealed that mithramycin exhibited anti-MRSA and anti-VRE activity, which was very potent compared to Linezolid. As regimen for infectious disease can be of limited period as compared to lengthy cancer treatment, authors propose and hope that in future mithramycin and its analogs could be potential candidates for developing a suitable lead for treatment of such diseases.

\section{Acknowledgement}

The authors wish to thank the Management of Piramal Enterprises Limited for their encouragement and approvals provided for this article.

\section{References}

1. Haskell TH, Ryder A, Frohardt RP, Fusari SA, Jakubowski ZL, Bartz QR. The isolation and characterization of three crystalline antibiotics from streptomyces plicatus. J Am Chem Soc. 1958;80(3):743-47. doi: $10.1021 / \mathrm{ja0} 01536 \mathrm{a} 055$

2. Sobin BA, Routien JB, Rao KV, Marsh WS, Garretson AI. Mithramycins as transplanted tumor inhibiting agents. US. Patent 3646194 A. 1972.

3. Rohr J, Méndez C, Salas JA. The biosynthesis of aureolic acid group antibiotics. Bioorg Chem. 1999;27(1):41-54. doi:10.1006/ bioo.1998.1110.

4. Blanco G, Fu H, Mendez C, Khosla C, Salas JA. Deciphering the biosynthetic origin of the aglycone of the aureolic acid group of antitumor agents. Chem Biol. 1996;3(3):193-6.

5. Lombó F, Blanco G, Fernández E, Méndez C, Salas JA. Characterization of Streptomyces argillaceus genes encoding a polyketide synthase involved in the biosynthesis of the antitumor mithramycin. Gene.1996;172(1):87-91.

6. Kennedy BJ, Griffen WO Jr, Lober P. Specific effect of Mithramycin on embryonal carcinoma of the testis. Cancer.1965;18(12):1631-6.

7. Kennedy BJ, Yarbro JW, Kickertz V, Sandberg-Wollheim M. Effect of Mithramycin on a mouse glioma. Cancer Res. 1968;28(1):91-7.

8. Kennedy BJ. Mithramycin therapy in advanced testicular neoplasms. Cancer. 1970 ;26(4): 755-66. doi: 10.1002/1097-0142 (197010) 26:4<755: :AID-CNCR2820260403>3.0.CO;2-U.
9. Miller DM, Polansky DA, Thomas SD, Ray R, Campbell VW, Sanchez J, et al. Mithramycin selectively inhibits transcription of G-C containing DNA. Am J Med Sci. 1987;294(5):388-9.

10. Blume SW, Snyder RC, Ray R, Thomas S, Koller CA, Miller DM. Mithramycin inhibits SP1 binding and selectively inhibits transcriptional activity of the dihydrofolate reductase gene in vitro and in vivo. J Clin Invest. 1991;88(5):1613-21.

11. Sastry M, Patel DJ. Solution structure of the mithramycin dimer-DNA complex. Biochemistry.1993;32(26):6588-604.

12. Sastry M, Fiala R, Patel DJ. Solution structure of Mithramycin dimers bound to partially overlapping sites on DNA. J Mol Biol. 1995;251(5):674-89.

13. Garcia-Bernardo J, Braña AF, Méndez C, Salas JA. Insertional inactivation of mtrX and mtrY genes from the mithramycin gene cluster affects production and growth of the producer organism Streptomyces argillaceus. FEMS Microbiol Lett. 2000;186(1):61-5.

14. Rodríguez D, Quirós LM, Braña AF, Salas JA. Purification and characterization of a monooxygenase involved in the biosynthetic pathway of the antitumor drug mithramycin. J Bacteriol. 2003;185(13):3962-5.

15. Jones ME, Blosser-Middleton RS, Thornsberry C, Karlowsky JA, Sahm DF. The activity of levofloxacin and other antimicrobials against clinical isolates of Streptococcus pneumoniae collected worldwide during 1999-2002. Diagn Microbiol Infect Dis. 2003;47(4):579-86.

16. Menichetti F. Current and emerging serious Gram-positive infections. Clin Microbiol Infect. 2005;11 Suppl 3:22-8.

17. Paterson DL, Bonomo RA. Extended-spectrum beta-lactamases: a clinical update. Clin Microbiol Rev. 2005;18(4):657-86.

18. Courvalin P. Vancomycin resistance in gram-positive cocci. Clin Infect Dis. 2006;42 Suppl 1:S25-34.

19. McDonald LC.Trends in antimicrobial resistance in health careassociated pathogens and effect on treatment. Clin Infect Dis. 2006;42 Suppl 2:S65-71.

20. Mutnick AH, Enne V, Jones RN. Linezolid resistance since 2001: SENTRY Antimicrobial Surveillance Program. Ann Pharmacother. 2003;37(6):769-74

21. Skiest DJ. Treatment failure resulting from resistance of Staphylococcus aureus to daptomycin. J Clin Microbiol. 2006;44(2):655-6.

22. O'Connor KA, Roth BL. Finding new tricks for old drugs: An efficient route for public-sector drug discovery. Nat Rev Drug Discov. 2005;4(12):1005-14.

23. Aleskog A, Norberg M, Nygren P, Rickardson L, Kanduri M, Tobin $\mathrm{G}$, et al. Rapamycin shows anticancer activity in primary chronic lymphocytic leukemia cells in vitro, as single agent and in drug combination. Leuk Lymphoma. 2008;49(12):2333-43. doi: 10.1080/10428190802475295.

24. Stoilova T, Colombo L, Forloni G. Tagliavini F, Salmona M. New face for old antibiotics: Tetracyclines in treatment of amyloidoses. J Med Chem. 2013;56(15): 5987-6006. doi:10.1021/jm400161p.

25. Osada N, Kosuge Y, Ishige K, Ito Y. Mithramycin, an agent for developing new therapeutic drugs for neurodegenerative diseases. J Pharmacol Sci. 2013;122(4):251-6.

26. Liacini A, Sylvester J, Li WQ, Zafarullah M. Mithramycin downregulates proinflammatory cytokine-induced matrix metalloproteinase gene expression in articular chondrocytes. Arthritis Research \& Therapy.2005;7(4):R777-R783. doi: 10.1186/ar1735. 
27. Kosuge $\mathrm{Y}$, Taniguchi $\mathrm{Y}$, Imai $\mathrm{T}$, Ishige $\mathrm{K}$, Ito $\mathrm{Y}$. Neuroprotective effect of mithramycin against endoplasmic reticulum stressinduced neurotoxicity in organotypic hippocampal slice cultures. Neuropharmacology. 2011;61(1-2):252-61. doi: 10.1016/j neuropharm.2011.04.009.

28. Fibach E, Bianchi N, Borgatti M, Prus E, Gambari R. Mithramycin induces fetal hemoglobin production in normal and thalassemic human erythroid precursor cells. Blood. 2003;102(4):1276-81.

29. Casamayor EO, Triadó-Margarit X, Castañeda C. Microbial biodiversity in saline shallow lakes of the Monegros Desert, Spain. FEMS Microbio Ecol. 2013;85(3):503-18. doi: 10.1111/1574-6941.12139.

30. Nathan P, Law EJ, Murphy DF, MacMillan BG. A Laboratory method for selection of topical antimicrobial agents to treat infected burn wounds. Burns. 1978;4(3): 177-87.

31. Bakhaeva GP, Berlin YA, Boldyreva EF, Chuprunova OA, Kolosov MN, Soifer VS, et al. The structure of aureolic acid (mithramycin) Tetrahedron Lett. 1968;(32):3595-8.

32. Methods for dilution antimicrobial susceptibility tests for bacteria that grow aerobically. 5th ed. Approved Standard M7-A5; Pennsylvania: National Committee for Clinical Laboratory Standards;2000.

33. Krishna NR, Miller DM, Sakai TT. NMR and fluorometric characterization of mithramycin in aqueous solution. J Antibiot

\section{(Tokyo). 1990;43(12):1543-52.}

34. Wohlert SE, Künzel E, Machinek R, Méndez C, Salas JA, Rohr J. The structure of mithramycin reinvestigated. J Nat Prod. 1999;62(1): 11921.

35. Cancer Connect newsletter. Mithracin. 2010. [Cited 2015 July 1] Available from: http://news.cancerconnect.com/mithracin/

36. González-Sabin J, Morís, F. Exploring novel opportunities for Aureolic Acids as anticancer drugs. Biochem Pharmacol. 2013;2 (1). doi: 10.4172/2167-0501.1000e140.

37. ClinicalTrials.gov/A service of the U.S. National Institutes of Health. Mithramycin for Children and Adults With Solid Tumors or Ewing Sarcoma. 2012. [Cited 2015 July 1]. Available from: http:// clinicaltrials.gov/show/NCT01610570

38. ClinicalTrials.gov/A service of the U.S. National Institutes of Health. Mithramycin for Lung, Esophagus, and Other Chest Cancers. 2012. [Cited 2015 July 1]. Available from: http://clinicaltrials.gov/show/ NCT01624090

39. Núñez LE, Nybo SE, González-Sabín J, Pérez M, Menéndez N, Braña AF, et al. A novel mithramycin analogue with high antitumor activity and less toxicity generated by combinatorial biosynthesis. J Med Chem. 2012;55(12):5813-25. doi: 10.1021/jm300234t. 